\title{
Applications of Aloe vera, as herbal, in the treatment of healing of skin diseases: a review of the literature
}

\author{
Júlia Oliveira Machado1; Dayana Correia de Almeida²; Luciano Lins Júnior ${ }^{3}$; Mateus Henrique \\ Aragão de Sales ${ }^{4}$; Anthony Batista da Silva Matias ${ }^{5}$; Mauricio Luiz de Oliveira ${ }^{6}$; Elymax Miquéias \\ Lima Teodosio dos Santos ${ }^{7}$; Cristiane Rodrigues ${ }^{8}$; Elaina Alves dos Santos ${ }^{9}$; José Ricardo de França \\ Silva ${ }^{10}$; Maria Eduarda da Silva Barbosa ${ }^{11}$; Samia Dayana Lemos de Lacerda ${ }^{12}$; Thiago David dos \\ Santos Silva ${ }^{13}$; Allyson Rodrigo de Oliveira Lopes*14 \\ 1 Graduated from the Bachelor of Pharmacy Course at the University Center of Vitória de Santo Antão - UNIVISA. \\ 2 Undergraduate of the Bachelor of Pharmacy Course at the University Center UNIFACOL - UNIFACOL. \\ 3 Nurse, Postgraduate in Urgency and Emergency and ICU. \\ 4 Bachelor of Pharmacy University Center UNIFACOL. \\ 5 Undergraduate degree in pharmacy degree at the Academic Center of Vitória de Santo Antão - UNIVISA. \\ 6 Undergraduate degree in Pharmacy degree at the Academic Center of Vitória de Santo Antão - UNIVISA. \\ 7 Undergraduate degree in pharmacy degree at the Academic Center of Vitória de Santo Antão - UNIVISA. \\ 8 Bachelor's degree in Pharmacy at the Academic Center of Vitória de Santo Antão - UNIVISA. \\ 9 Bachelor's degree in pharmacy from the Academic Center of Vitória de Santo Antão - UNIVISA. \\ 10 Undergraduate graduated from the bachelor's degree in Pharmacy at the Academic Center of Vitória de Santo Antão - UNIVISA. \\ 11 Bachelor's degree in Pharmacy at the Academic Center of Vitória de Santo Antão - UNIVISA. \\ 12 Master in Human Health and Environment - UFPE \\ 13 Pharmacist, professor of the health center of the University Center UNIFACOL - UNIFACOL. \\ 14 Professor of the Bachelor of Pharmacy course at the University Center of Vitória de Santo Antão - UNIVISA.
}

E-mail adresses: Juh_machado4@hotmail.com (Júlia Oliveira Machado), dayanacorreia18@gmail.com (Dayana Correia de Almeida), lucianolinsjr@hotmail.com (Luciano Lins Júnior), mateus-cbjr-br@hotmail.com (Mateus Henrique Aragão de Sales) tony_toic01@hotmail.com (Anthony Batista da Silva Matias), mlomauricio15@gmail.com (Mauricio Luiz de Oliveira) elymaxmiqueias19@gmail.com (Elymax Miquéias Lima Teodosio dos Santos), cristianer2013@gmail.com (Cristiane Rodrigues), elainaalves2829@gmail.com (Elaina Alves dos Santos), ricardo_franca1@hotmail.com (José Ricardo de França Silva), barbosa.mariaeduarda0023@gmail.com (Maria Eduarda da Silva Barbosa), samia.lacerda@ufpe.br (Samia Dayana Lemos de Lacerda), thiagodavid_10@hotmail.com (Thiago David dos Santos Silva), allysonlopes85@gmail.com (Allyson Rodrigo de Oliveira Lopes).

${ }^{*}$ Corresponding author

\section{To cite this article:}

Machado, J.O.; Almeida D.C.; Júnior, L.L.; Sales, M.H.A.; Matias, A.B.S.; Oliveira, M.L.; Santos, E.M.L.T.; Rodrigues, C.; Santos, E.A.; Silva, J.R.F.; Barbosa, M.E.S.; Lacerda, S.D.L.; Silva, T.D.S.; Lopes, A.R.O. Applications of Aloe vera, as herbal, in the treatment of healing of skin diseases: a review of the literature. International Journal of Sciences. Vol. 2, No. 1, 2021, pp. 01-05. ISSN $2763-5392$.

Received: 06 29, 2021; Accepted: 06 30, 2021; Published: 07 15, 2021

\begin{abstract}
The use of medicinal plants has modernized over the years, from the easiest ways of treatment to the most technological forms of industrial handling used by modern man. Aloe vera, popularly known in Brazil as aloe vera has been used for thousands of years in traditional medicine for various treatments. The work aimed to make a bibliographic survey of articles that point to the pharmacological action of Aloe vera. It was found that several biological activities are attributed to aloe. Evidence suggests efficacy in the treatment of psoriasis, genital herpes, burns and hyperglycemia. Based on the material studied, it is concluded that in folk medicine, it serves to heal wounds, bruises, irritations, tonics, purgatives and gastritis. In view of the several proven activities and few cases of contraindication, it is concluded that the use of the species corroborates the vast popular use.
\end{abstract}

Keywords: Aloe Vera; Babosa; Gastritis. 


\section{Introduction}

Since antiquity, men have sought in nature methods to favor their living conditions, in an attempt to extend their chances of survival. The peoples of Greek, Egyptian and other civilizations already dealt with plants in the treatment of the diseases of humanity (PONTES et al., 2013). The use of medicinal plants has modernized over the years, from the easiest ways of treatment, certainly used by caveman, to the most technological forms in the industrial management used by modern man (LORENZI; SOUZA, 2012).

The use of medicinal plants, in treatments of various diseases, is usually a frequent habit in several cultures around the world, and their teachings are followed through the generations. According to the World Health Organization, it is estimated that approximately $80 \%$ of the population uses herbal products, whether or not they have scientific evidence (MERCÊS, 2017).

Aloe vera, species of succulent plant of the genus Aloe, has been used in traditional medicine for thousands of years, as in ancient Egypt, by Cleopatra in hair and skin care. It is popularly known in Brazil as a loot, for containing on its leaves a gel known as baba. However, Aloe vera probably originates from the Arabic word alloeh, whose meaning is bitter and brilliant (FREITAS; RODRIGUES; GASPI, 2014).

Used in the treatment of cell regeneration with stimulations of tissue growth because it contains antiinflammatory and healing action. It has great importance because it has vitamins of type $\mathrm{C}$ and $\mathrm{E}$, mineral salts and amino acids that are essential to humans, with amounts appropriate for health (RAMOS; PIMENTEL, 2011).

The gel has as action, anticipate the healing process, entering through the skin tissues, causing the wound to become moist, thus decreases the process inflates the amatory protecting circulation. Presenting as one of its functions, the antioxidant action (LIMA, et al, 2018).

Scientific studies of the cosmetics industry present quality arising from its therapeutic effects. Although it prorogues the treatment, the result is satisfactory, having a good success in phytotherapy (RIGOTTI, 2014).

In the treatment of psoriasis, a chronic inflammatory skin disease that affects about $6 \%$ of the population, a loathing can be used. Clinical studies prove the efficacy of Aloe vera in reducing side effects. Its use in the treatment of psoriasis is because corticosteroids, when applied for a long time, may have the opposite effect than expected. It is a viable alternative in the treatment and can be used associated or isolated (ALMEIDA; RODRIGUES; CARVAHO, 2019).

Recent research has concluded that when Aloe vera is applied to the skin, there is increased surface tension and collagen removal, producing new blood vessels and increased oxygenation, thereby reducing inflammation (RAMALHO et al., 2018).

Indirectly, traditional medicinal culture stimulates the interest of researchers in studies relating the areas of botany, pharmacology and phytochemistry, which add knowledge about the inexhaustible source of natural medicine: the world flora (MACIEL et al., 2012).

This work aims to raise evidence of the use of Aloe Vera, its properties and main uses. In Brazil, medicinal plants have been a possibility of wide importance in wound healing and other complications. Several studies describe its cost benefit and proof of use as a medicine (LOPES, 2016).

\section{Methodology}

The research methodology is explored by a sequence of topics, which aim to describe and analyze the results proposed in the study. The research as to its nature can be descriptive or inferential, we will use in our study of inferential nature, with generalizations.

According to Ruiz (2010), a research is the concrete realization of what was researched, through planned investigations, developed and written according to existing standards.

The study consists of a theoretical literature review of descriptive studies on the study of aloe vera in the treatment of healing of skin diseases.

Based on articles inserted in lilacs, SciELO and Pubmed databases. In addition to searching in books and theses in the Nestor Library of Holland of UNIVISA. Informationwas extracted in relation to the main objectivesof thestudy, where a synthesis of the results was carried out.

\section{Results}

\subsection{Phytotherapy Concept}

According to the dictionary (Aurelius, 2016) phytotherapy is the science that studies medicinal plants and their use in the treatment of diseases. The word "phytotherapy" comes from the Greek terms (therapeia $=$ treatment + phyton = vegetable) and means "therapy by plants".

Phytotherapy is the method of treatment of diseases that employs fresh vegetables, plant drug or even vegetable extract prepared with these two types of raw materials. Etymologically, phytotherapy means treatment through plants. (FERREIRA; PINTO, 2010)

Medicinal plants undoubtedly correspond to the oldest weapons used in the treatment of human and animal diseases. There was a time, however, when phytotherapy seemed to be dying. The chemical-pharmaceutical industry produced the most diverse types of drugs, which were effective in the treatment of various types of diseases. However, the cost of these drugs was increasing. Much of the world's population remained marginalized and without access to these benefits.

On the other hand, side effects resulting from the use of drugs obtained by synthesis were increasingly frequent. There was no advantage in treating one evil quickly and efficiently by introducing another. Medicines needed to be both effective, safe and affordable for all.

Phytotherapy fits as a therapy with the function of assisting in the healing of deep pathologies, with low cost and without aggressiveness, because it incites the natural defenses of the organism and reintegrates the human being to its terrestrial roots. (FERREIRA; PINTO, 2010)

\subsection{Drug research and development process}

The process of research and development of new drugs is deeply associated with medicinal chemistry. Medicinal chemistry encompasses the creation, discovery, planning, 
identification, preparation and interpretation of the molecular mode of action of biologically active compounds used in the R\&D (Research and Development) process. Clarifying the relevance of the formation of fundamental connection between the chemical, biological, pharmaceutical, medical, physical and computational sciences (GUIDO et al., 2010).

The authors BERKOWITZ (2006) and GUIDO et al. (2010) re-described the R\&D process as the exploration or synthesis of a molecule with active potential and its binding with an appropriate biological purpose configuring the beginning of the process. By law, the safety and efficacy of drugs must be determined prior to marketing. Subsequently, in addition to in vitro studies, the in vivo studies, which will specify the biological consequences of the molecule in animals (pre-clinical tests) will be carried out by the pharmaceutical industry before clinical studies in humans are initiated.

\subsection{History of Aloe vera}

The history of Aloe vera since antiquity is found in the literature of different societies. Its name originates from the Arabic word alloeh, which means bitter and brilliant substance. Known in ancient Egypt as the "pltapir of immortality", it was used by Cleopatra in skin and hair care (ALONSO, 2007).

Aloe vera Lamiaceae Burm. f., most commonly used in herbal medicines, belongs to the Family Aloaceae that covers more than 15 genera and 800 species. Herbaceous plant that grows in any soil, but is better adapted to light and sandy and with little water consumption. With green leaves, thick, juicy, they measure between 30 and 60 centimeters in length. Its flowers are showy, presenting yellowish white tint, tubular shape (LORENZI; MATOS, 2008).

The literature includes several synonymies Aloe barbadensis Mill., Aloe barbadensis var. chinensis Haw., Aloe perfoliata var. vera L., Aloe chinensis Bak. and Aloe vera var. chinensis Berger. In the popular is called aloe, aloe, aloe-deBarbados and aloe-de curacao (LORENZI; MATOS, 2008).

In 1932, it was recognized by the British Pharmacopoeia as an official drug and inserted in other pharmacopoeias. He arrived in Brazil through merchants to serve the London market in 1693. In 1843, considerable sums were imported. Currently it is very common in Brazil where it is popularly used in wound healing, in the treatment of burns, conjunctivitis, rheumatic pain, among other ailments. Currently, Aloe vera is planted on a large scale in Panama, such as Mexico, USA and China (LORENZI; MATOS, 2008).

\section{4 Parts used in therapy}

Aloe vera needs about four to five years to reach maturity, and its leaves can be divided into two parts. The outermost one can extract a juice of dark brown coloring, concentrated and dry Cham that of Aloe, which flows spontaneously from the cut leaves, and has forte odor and taste quite bitter. It has composition mainly of anthracitic derivatives, and alliins (barbaloin and is barbaloin) are the most known (WHO, 1999).

After removing the outermost tissues from the leaf, there is a viscous and colorless mucilaginous gel called Aloe vera gel. Formed mainly by water and polysaccharides, and more than 70 other components such as vitamin $\mathrm{A}, \mathrm{B}, \mathrm{C}$ and $\mathrm{E}$, calcium, potassium, magnesium and zinc, various amino acids, enzymes and carbohydrates. (SURJUSHE, 2008). Gel is widely used as a raw material in the cosmetic, food and pharmaceutical industry and numerous techniques are used for its conservation (CUNHA, 2005).

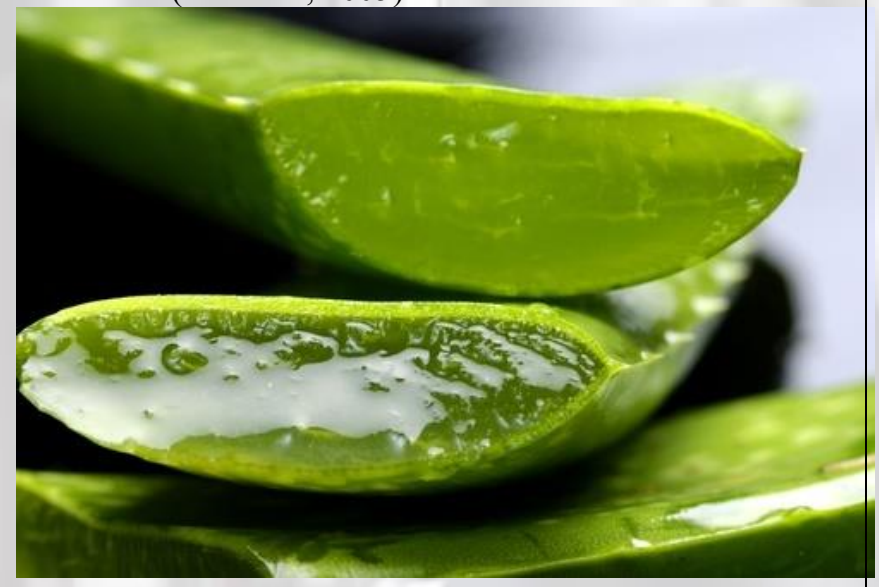

Figure 1: Aloe vera fractionated. Source: Ferreira e Pinto, (2010).

It is noteworthy that seasonal and crop changes affect the composition of the gel. Polysaccharide levels, for example, are lower in irrigated plants. Leaf processing should be done immediately after harvest, as the gel oxidizes rapidly when it comes into contact with air (RODRÍGUEZ-GONZÁLEZ et al., 2011).

Pasteurization is the most used processing technique by the industry and one of the suggested techniques is HTST (high temperature, time, short) which consists of heating the gel at $65^{\circ} \mathrm{C}$ for 15 minutes followed by rapid cooling at $5^{\circ} \mathrm{C}$. Promoting the decrease in acemanan levels, one of the bioactives of the gel, in addition to other changes in pasteurized samples at $85^{\circ} \mathrm{C}$. (RODRÍGUEZ-GONZÁLEZ et al.,2011). Another method also used is dehydration, which causes significant losses of acemanan and other compounds when the samples were treated with temperatures above $60^{\circ} \mathrm{C}$. (FEMENIA et al., 2003)

\subsection{Chemical Composition}

The chemical composition of Aloe vera has a large number of polysaccharides, minerals, enzymes, among others present in its leaves. However, each structure of Aloe has specific substances. According to Silva (2004), the latex sheet has, as shown in the table below:

Table 1: Chemical composition.

\begin{tabular}{|c|c|}
\hline leaf & gel \\
\hline $\begin{array}{l}\text { Glycosated anthraline (15- } \\
30 \%) \text { : Barbaloin }(20 \%) \text {, beta- } \\
\text { barbaloin, isobarbaloin, aloe- } \\
\text { emodin-9-antranone, } \\
\text { alloinoside glycosides A and }\end{array}$ & $\begin{array}{l}\text { Water }(95 \%) \text { together with } \\
\text { bradymycin, magnesium } \\
\text { lactate, acemanan }\end{array}$ \\
\hline
\end{tabular}


4 Machado, J.O.; Almeida D.C.; Júnior, L.L.; Sales, M.H.A.; Matias, A.B.S.; Oliveira, M.L.; Santos, E.M.L.T.; Rodrigues, C.; Santos, E.A.; Silva, J.R.F.; Barbosa, M.E.S.; Lacerda, S.D.L.; Silva, T.D.S.; Lopes, A.R.O. Applications of Aloe vera, as herbal, in the treatment ...

\begin{tabular}{l|l}
\hline B, alloin & \\
\hline $\begin{array}{l}\text { Resin (15-70\%): Kinetic acid, } \\
\text { aloeresins A, B, C and D }\end{array}$ & $\begin{array}{l}\text { Polysaccharides (0.2- 0.3\%) } \\
\text { Glicomano, manano, mucilage }\end{array}$ \\
\hline $\begin{array}{l}\text { Manosa mucilage, glycosa, } \\
\text { arabinosa, galactosa and }\end{array}$ & $\begin{array}{l}\text { Glycanic, } \\
\text { peteroilglutamic, salicilic acids }\end{array}$ \\
xylose & \\
\hline $\begin{array}{l}\text { Enzymes Oxidase, Catalase, } \\
\text { Amylose }\end{array}$ & Enzymes Oxidase, aliinase, \\
\hline $\begin{array}{l}\text { Other essential oils, flavone, } \\
\text { aloesone, aloetine, emodine, }\end{array}$ & Linoleic gammaacid; Lignin; \\
uronic acid, gum, flavanones & \\
\hline $\begin{array}{l}\text { Amino acids lysine, threonine, } \\
\text { valine, methionine, leucine, }\end{array}$ & Vitamins A, C, E, and some of \\
the B complex \\
tryptophan, histidine arginine, \\
hydroxyproline,
\end{tabular}

Source: Adapted, Silva (2004)

According to its nutritional value, its vast diversity of elements present in its structure is observed. Thus, having pharmacological activities that act in the body, providing antiinflammatory effects, antibiotics, emollients, moisturizers, among others.

\section{6 "Babosa" Therapeutic Action}

The cosmetic use of aloe is very popular, especially for its capillary function to combat alopecia. However, the Aloe vera function in the human body is much greater, acting from headaches to even cancer. Dr. Peter Atherton (1997) describes some of the therapeutic properties of aloe. According to him, the plant has:

Table 2: Therapeutic Properties.

\begin{tabular}{l|l}
\multicolumn{1}{c|}{ Substances } & \multicolumn{1}{c}{ Properties } \\
\hline Saponins & antiseptic \\
\hline lignin & penetrating power \\
\hline Salicylic acid & $\begin{array}{l}\text { anti-inflammatory and } \\
\text { bactericidal }\end{array}$ \\
\hline Alloin & Laxative and vermifugus \\
\hline vitamins A, C, E and B12 & anti-inflammatory and analgesic \\
\hline fibroblasts & $\begin{array}{l}\text { Immunomodulator, antiviral, } \\
\text { healing and collagen }\end{array}$ \\
\hline
\end{tabular}

Source: Adapted by Atherton, 1997

In 2009, the Ministry of Health made a list of 71 plants of interest to the Unified Health System -SUS, which describe the great therapeutic potential among the medicinal plants presented, only Babosa is antiulcer (BRASIL, 2009).

Aloe's therapeutic actions are the same as all liliaceous ones, but it acts more intensely and with depth to tone and stimulate all metabolism, especially stomáquic, reathing the stomach dysfunctions, in addition to purgative, collagen, which increases bile secretion. As a topical use, it favors the healing of wounds, including stomach stooes. It is a plant that combines a strong vitality to a contained sulfurous inflammation, actively encompasses the constituents of the human being dissociated by disease or injury, stimulating regeneration and calming suffering. (PELIKAN, 2007).

\section{Conclusions}

The insufficient source of references about the industrialization and/or manipulation of medicinal plants is very small and the theoretical basis on several species already commercialized in the country is quite restricted. And thus, there are few agronomic, pharmacological, toxicological, development of pharmaceutical forms and scientific studies in the production of herbal products.

However, free fairs, herbalists, small industries and pharmacies market such species even if there is resolution RDC 17 that determines the study of plants before they are marketed. There is a lack of incentive from industries, with participation in universities, thus financing research in different areas that constitute phytotherapy.

\section{Acknowledgments}

To my parents, who have always believed in me and encouraged me by showing that I am capable. To my teachers who contributed to my training and learning. To my advisor, Professor Allyson Lopes who has always been by my side all the time giving all the support I needed.

\section{References}

[1] BRASIL. Lei n. ${ }^{\circ} 10.213$ de 28 de março de 2009. Define normas de regulação para o setor de medicamentos, institui a Fórmula Paramétrica de Reajuste de Preços de Medicamentos FPR, cria a Câmara de Medicamentos e dá outras providências. Diário Oficial [da] República Federativa do Brasil, Brasília, 28 mar. 2009. Seção 1. 4.

[2] CUNHA, L. E. M., Plantas Medicinais - do cultivo a terapêutica - São Paulo, $3^{\mathrm{a}}$ Ed., Ed. Vozes, 2005.

[3] FERREIRA, V. F.; PINTO, A. C. A fitoterapia no mundo atual. SP. Quím. Nova. 2010, vol.33, n.9, pp. 1829-1829.

[4] FREITAS, Rosendo A.; RODRIGUES, Rozangela Curi e GASPI, Valdir. Fármacos e fitoterápicos: a necessidade do desenvolvimento da indústria de fitoterápicos e fitofármacos no Brasil. Quím. Nova 2014.

[5] GUIDO G.K. et al. Oportunidades na indústria de medicamentos e a lógica do desenvolvimento local baseado nos biomas brasileiros: bases para a discussão de uma política nacional. Cad. Saúde Pública, Rio de Janeiro, 2010. 
[6] LIMA, et al. Ética e pesquisa médica: princípios, diretrizes e regulamentações. Revista da Sociedade Brasileira de Medicina Tropical. Uberaba, v.38, n.4, p.334-347, 2018.

[7] LORENZI, H.; SOUZA, V.C. Botânica sistemática: guia ilustrado para a identificação das famílias de Angiospermas da flora brasileira, baseado em APG II. 2 ed. nova Odessa: Instituto Plantarum, 2008.

[8] MACIEL. Farmacognosia - curso teórico prático. Fortaleza: Editora UFC, 1989. 2012.

[9] PONTES. Técnica farmacêutica e Farmácia Galénica. 4.ed. Lisboa: Fundação Calouste Gulbenkian, 2012.

[10] FEMENIA. A utilização de fitoterapia no cotidiano de uma população rural. Revista Escola Enfermagem USP 2003; 36(3): 282-8.

[11] RAMALHO. A pesquisa e a produção brasileira de medicamentos a partir de plantas medicinais: a necessária interação da indústria com a academia. Rev. bras. Farmacognosia, 2018, vol.12, n.1.

[12] SILVA, Irenice. Noções Sobre o Organismo Humano e Utilização de Plantas Medicinais. Universidade Estadual de Maringá, SP. 2004. 